\title{
Assessing Permafrost Degradation and Land Cover Changes (1986-2009) using Remote Sensing Data over Umiujaq, Sub-Arctic Québec
}

\author{
Inga Beck, ${ }^{1 *}$ Ralf Ludwig, ${ }^{2}$ Monique Bernier, ${ }^{3}$ Esther Lévesque ${ }^{4}$ and Julia Boike ${ }^{1}$ \\ 1 Alfred Wegener Institute for Polar and Marine Research, Potsdam, Germany \\ 2 Department of Geography, Ludwig-Maximilians University, Munich, Germany \\ ${ }^{3}$ Centre Eau, Terre \& Environnement, Institut national de la recherche scientifique, Québec, Canada \\ 4 Département des sciences de l'environnement et centre d'études nordiques, Université du Québec à Trois-Rivières, Trois-Rivières, Canada
}

\begin{abstract}
Recent land cover changes in the Umiujaq region of northern Québec, Canada, have been quantified in order to estimate changes in the extent of discontinuous permafrost that strongly affect the forest-tundra ecotone. Changes in the areas covered by different vegetation types, thermokarst lakes and degradation of lithalsas have been investigated over an area of $60 \mathrm{~km}^{2}$, extending from widespread discontinuous permafrost in the north to areas of scattered permafrost in the south, and from Hudson Bay in the west to the Lac Guillaume-Delisle graben $10 \mathrm{~km}$ further east. We used high-resolution remote sensing images (QuickBird 2004, GeoEye 2009) and four Landsat scenes (1986, 1990, 2001, 2008) as well as ground-based data (vegetation, active layer thickness, snow parameters) collected between 2009 and 2011. Two change detection methods applied to estimate the land cover changes between 1986 and 2009 showed an overall increase in vegetation extent between 1986 and 2009, and a 21 per cent increase in tall vegetation (spruce and tall shrubs) between 2004 and 2009 at the expense of low vegetation (lichens, prostrate shrubs, herbaceous vegetation). Thermokarst lakes and lithalsas in ten sub-areas were mapped manually from satellite imagery. The area covered by water decreased by 24 per cent between 2004 and 2009, often due to vegetation colonising the margins of lakes, and 93 of the observed lakes disappeared completely over that period. The area covered by lithalsas declined by 6 per cent. Our results demonstrate the viability of using high-resolution satellite imagery to detect changes in the land surface that can serve as indicators of permafrost degradation in the sub-Arctic. Copyright (C) 2015 John Wiley \& Sons, Ltd.
\end{abstract}

KEY WORDS: permafrost; vegetation changes; remote sensing; thermokarst ponds; lithalsas

\section{INTRODUCTION}

Permafrost temperatures have increased across the northern hemisphere since the 1950s. The smallest recorded increase $\left(<1^{\circ} \mathrm{C}\right)$ was from the Tibetan Plateau (Zhao et al., 2004) and the largest increase $\left(4^{\circ} \mathrm{C}\right)$ was from northern Alaska between the 1910s and the 1980s (Lachenbruch and Marshall, 1986). The temperature increase is reflected in the rate of permafrost thaw, which has ranged from $0.04 \mathrm{~m} /$ year since 1992 in Alaska to $0.02 \mathrm{~m} /$ year since 1960 on the Tibetan Plateau (Lempke et al., 2007). In the Umiujaq area in northern Québec, the mean annual ground temperature (MAGT) at $20 \mathrm{~m}$ depth has increased by $0.9^{\circ} \mathrm{C}$ between 1998 and

* Correspondence to: I. Beck, Alfred Wegener Institute for Polar and Marine Research, Am Telegrafenberg 43 A, 14473 Potsdam, Germany. E-mail: inga.may@awi.de
2006 (Fortier et al., 2011). The increase in MAGT has been accompanied by active layer deepening and permafrost degradation.

The thawing of frozen ground leads to substantial changes in the complex geo-ecological system. Thermokarst lakes result from the melting of ground ice, which leads to ground subsidence (Williams and Smith, 1989). Lithalsas and palsas are typical frost mounds of the ice-rich discontinuous permafrost zone (Seppäla, 1988). The main difference between them is that palsas are covered by a peat layer that tends to collapse when their frozen cores melt (Pissart, 2002). Morphologically, lithalsas and palsas are normally low circular or oval features, around $5 \mathrm{~m}$ high, 10-30 m wide and up to $150 \mathrm{~m}$ long. The ice lenses within their permafrost cores are usually no thicker than $3 \mathrm{~cm}$, but may reach thicknesses of $40 \mathrm{~cm}$ (Gurney, 2001; Pissart, 2002). Their anticipated thawing with continued warming is likely to have severe 
direct and indirect consequences for ecosystems, hydrological regimes, vegetation and human populations (Nelson et al., 2003).

Changes in the land surface within our study area around Umiujaq in northern Québec have been attributed to permafrost thaw. Laberge and Payette (1995) reported a 33 per cent reduction in the total area of permafrost, based on palsa monitoring from aerial photographs acquired between 1983 and 1993. Fortier and Aubé-Maurice (2008) described permafrost degradation that has occurred near Umiujaq since 1957, based on aerial photographs from 1957, 1983 and 2003, and an IKONOS scene from 2005. Their results indicated that permafrost degradation was already occurring in 1957 and that the rate of degradation has increased in recent years, from an annual loss of -380 $\mathrm{m}^{2}$ or -0.8 per cent between 1957 and 1983 (26 years), to almost twice that amount $\left(-640 \mathrm{~m}^{2}\right.$ or $\left.-1.6 \%\right)$ between 1983 and 2005 (22 years). The increase was attributed to the increase in air temperature of at least $3^{\circ} \mathrm{C}$ observed since 1992.

Such observed changes and their potential consequences highlight the need to detect the spatial distribution and intensity of permafrost dynamics. The use of aerial photography can deliver major benefits compared to point measurements, but the spatial extent of aerial photographs is limited compared to that of satellite imagery. However, detecting permafrost from space is not simple as permafrost is a sub-surface phenomenon.

Most of the currently used approaches to permafrost monitoring therefore make use of surface indicators detectable from space. Hinkel et al. (2007) studied the drainage of thaw lakes in northern Alaska by means of Landsat images; Panda et al. (2010) used SPOT 5 images with a spatial resolution of $10 \mathrm{~m}$ to identify changes in geomorphological units in Alaska; Stow et al. (2004) analysed products from the advanced very high resolution radiometer advanced very high resolution radiometer (AVHRR) ( $8 \mathrm{~km}$ resolution) to derive information on vegetation cover using the normalised difference vegetation index normalised difference vegetation index (NDVI) for study sites on the North Slope, Alaska; and Raynolds and Walker (2008) and Kelley et al. (2004) used the NDVI as an indicator of the underlying soil conditions in Northern America. Although these studies have presented valuable results, the surface features that can be detected are limited by the spatial resolution of the data. According to Muster et al. (2013), this scale problem leads to a major underestimation of Arctic water bodies, which would affect the validity of any quantitative conclusions.

In addition to detecting objects using the visible (VIS) and near-infrared (NIR) spectral bands, some sensors use the thermal infrared (IR) band to record land surface temperatures. IR has been used for permafrost studies: Hachem et al. (2009) used Moderate Resolution Imaging Spectroradiometer MODIS data for northern Canada, Langer et al. (2013) for northern Siberia and Westermann et al. (2011) for $\mathrm{Ny}$ Alesund, Svalbard. Jones et al. (2012) and Liu et al. (2014) even applied high-resolution interferometric synthetic aperture radar to assess the distribution of pingos and to detect the dynamics of thermokarst lakes (Liu et al., 2014) on the North Slope of Alaska.
These studies have demonstrated the viability of indirectly obtaining information on soil conditions. When interpreting results, however, it is important to bear in mind that: (i) only objects that are at least as large as the spatial resolution of the images are detectable; and (ii) while some changes in the land cover can be caused by changes in permafrost, some land cover changes may also trigger changes in permafrost (Åkerman and Johansson, 2008; Jorgenson et al., 2001; Raynolds and Walker, 2008).

Overcoming the problem of scale requires high-resolution images. However, such data are expensive, the time resolution is low and long time series are not available. In order to overcome these problems, the present study combines different spatial and temporal resolutions. We used highresolution satellite imagery (QuickBird and GeoEye) to detect small land surface features and to reveal the limitations of low-resolution images. The results were validated against field data. We identified land cover changes (vegetation, thermokarst lakes, lithalsas) between 2004 and 2009. Since this only covered a 5 year period, the long-term trends observed in the Landsat image series were taken into account to detect previous changes. This study therefore extends the spatial and temporal scale of the Fortier and Aubé-Maurice (2008) study along the Hudson Bay coastline through the use of new satellite imagery.

\section{STUDY AREA}

The study was conducted over an area of approximately 60 $\mathrm{km}^{2}$ around the Inuit village of Umiujaq $\left(56^{\circ} 33^{\prime} \mathrm{N}, 76^{\circ}\right.$ $\left.33^{\prime} \mathrm{W}\right)$, close to the eastern coastline of Hudson Bay in Nunavik, northern Québec, Canada (Figure 1). The area lies in the transition zone between the sub-Arctic and the low Arctic, where a high sensitivity to climate changes is expected. Good long-term climatic and environmental records are available for the study area (Allard and Séguin, 1985), providing a valuable basis for investigating topographical changes.

This area has only 60 to 80 frost-free days per year (Environment Canada, 2004). The annual average air temperature is about $-5.5^{\circ} \mathrm{C}$ but due to the cooling effect of Hudson Bay the region experiences high-amplitude temperature variations during the year. From June until midDecember, the region has a maritime climate, with relatively small daily variations and moderate temperatures of around $8^{\circ} \mathrm{C}$. In contrast, when Hudson Bay freezes over during winter temperatures can fall below $-30^{\circ} \mathrm{C}$ due to continentality. Annual average wind speeds are 20 to 24 $\mathrm{km} / \mathrm{h}$ (Gagnon and Ferland, 1967). The average annual precipitation is approximately $500 \mathrm{~mm}$ of which 37 per cent falls as snow (Environment Canada, 2004).

The area can be divided geomorphologically into a coastal region, with a gently sloping topography, and the Lac Guillaume-Delisle graben (Figure 1), separated by cuestas made up of volcanic sedimentary rock (Kranck, 1951). Shrubs dominate the coastal region, whereas the 


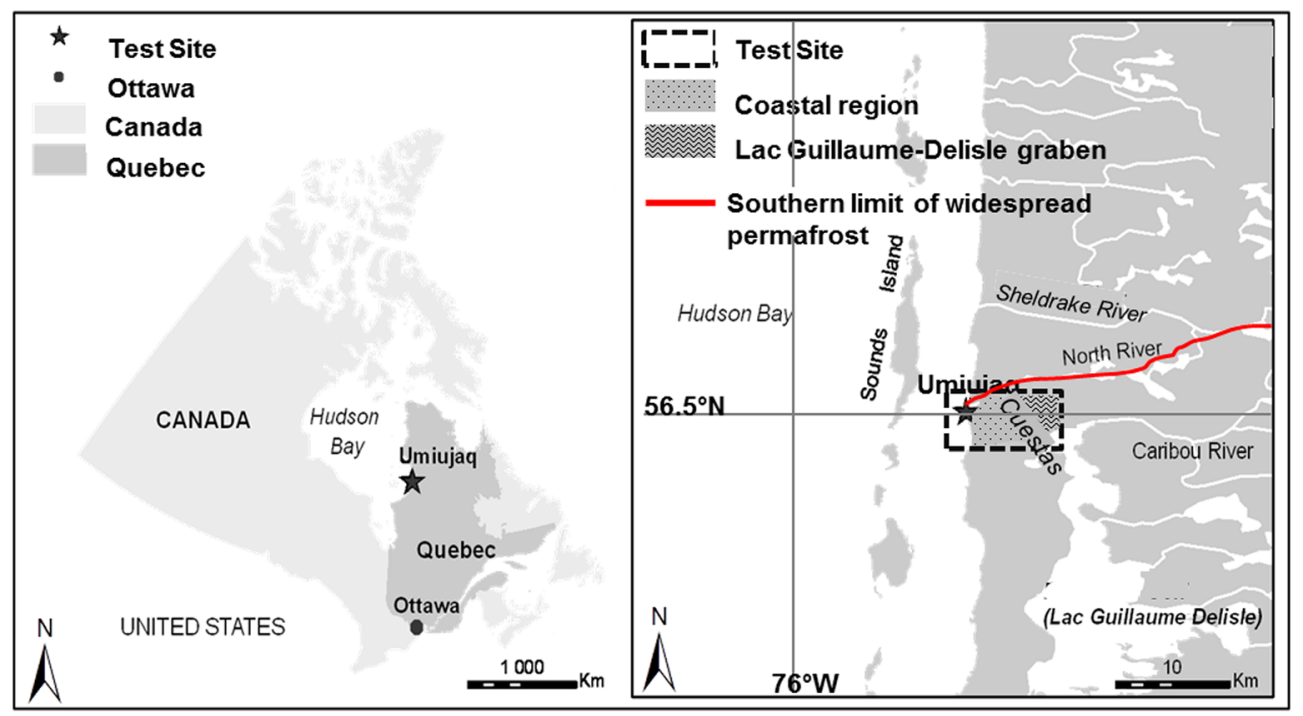

Figure 1 Location of the Umiujaq study area in northern Quebec, Canada, also showing the distribution of the two main landscape types: the coastal region to the west of the cuestas and the Lac Guillaume-Delisle graben to the east of the cuestas. The boundary between the widespread discontinuous permafrost to the north and the scattered permafrost to the south (based on Allard and Séguin, 1987) is shown in red. This figure is available in colour online at wileyonlinelibrary.com/journal/ppp

Lac Guillaume-Delisle graben area also includes isolated tree islands and localised forest patches, mostly black spruce (Picea mariana). Thus, the study area is located in the forest-tundra ecotone, which consists mainly of scattered bodies of permafrost and straddles the northern timber line (Figure 1). The MAGT is around $-2.5^{\circ} \mathrm{C}$ at a depth of $10 \mathrm{~m}$ (Smith et al., 2010). This transitional location makes the study area ideal for detecting changes in vegetation and permafrost, and associated land surface changes.

Air temperatures in the region around Umiujaq are expected to increase by up to $10^{\circ} \mathrm{C}$ over the next 40 years, with the rate of increase expected to be highest during winter (Allard et al., 2007). Such increased air temperatures are expected to increase soil temperatures by approximately $4^{\circ} \mathrm{C}$. The modelling results obtained by Sushama et al. (2006) suggest significant deepening of the active layer in the future that would likely result in changes to the land surface, as well as affecting vegetation patterns due to altered soil conditions (Åkerman and Johansson, 2008; Osterkamp and Romanovsky, 1999).

\section{REMOTE SENSING DATA}

This study used all available images covering the period from 1986 to 2010 that met the requirements with respect to spatial resolution $(<30 \mathrm{~m})$, temporal resolution (1 year period), and spectral resolution (at least the VIS and NIR bands) (Table 1). Many of the available acquisitions could not be utilised as the cloud cover was too extensive.

Six optical satellite images were used, acquired by four different sensors between 1986 and 2009 (Table 1). The four sensors were Landsat's Thematic Mapper, Landsat's Enhanced Thematic Mapper (Stein et al., 1999), the
QuickBird sensor and the GeoEye sensor (GeoEye Elevating Insight, 2011). The parameters for each of these sensors are listed in Table 1.

The QuickBird image comprised a mosaic of four scenes; the VIS and NIR bands (with a spatial resolution of $2.4 \mathrm{~m}$ ) were only available for the coastal region of the study area. A pan-sharpened acquisition with a spatial resolution of $0.61 \mathrm{~m}$ was available for the Lac Guillaume-Delisle graben, but it only contained channels in the VIS range. The image was made available by the working group of the Canadian Institut national de la recherche scientifique in the described format. The GeoEye image (from September 2009) was also pan-sharpened.

\section{METHODS}

\section{Field Data Acquisition}

Vegetation data and classes were derived from field sampling carried out in August 2009. A total of 245 plots were sampled (116 in the coastal region and 129 in the Lac GuillaumeDelisle graben), each having a radius of $5 \mathrm{~m}$ and covering nearly $80 \mathrm{~m}^{2}$. Plots were positioned within $30 \mathrm{~m} \times 30 \mathrm{~m}$ areas selected to cover a range of vegetation conditions between 1990 and 2004, ranging from stable to highly altered, based on a visual comparison between georeferenced aerial photographs (spatial resolution $0.25 \mathrm{~m}$, August and September 1990, provided by Hydro-Québec, Montréal, Québec, Canada) and the QuickBird image (July 2004). Within each $30 \mathrm{~m} \times 30 \mathrm{~m}$ area, one validation $5 \mathrm{~m}$ radius plot was established in a representative portion of the $30 \mathrm{~m} \times 30 \mathrm{~m}$ plot (generally the centre) and the vegetation characterised. Within each of these plots, the height and cover were assessed for each 
Table 1 Overview of the main parameters of sensors delivering data used in this study, together with the acquisition dates for the images used.

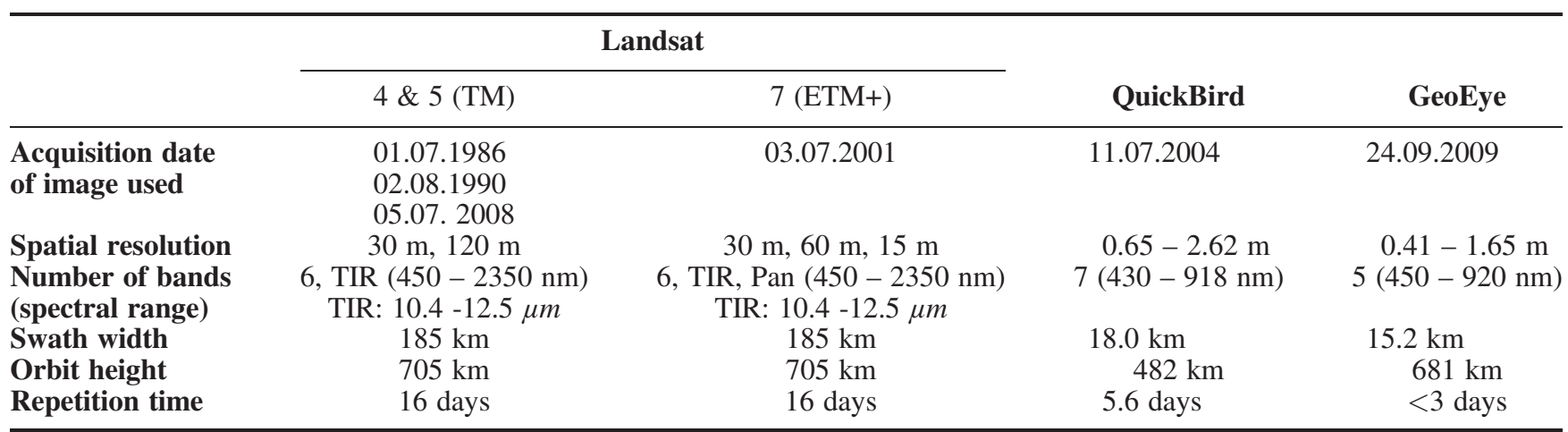

$\mathrm{TM}=$ Thematic Mapper; ETM+ = Enhanced Thematic Mapper.

woody plant species. The cover was evaluated using a modified Braun-Blanquet scale, similar to the Daubenmire classification (Wilson and Nilsson, 2009). The areas of exposed bedrock were recorded, as well as the areas covered by water and other cover types, the topographic position (top of slope, mid-slope and base of slope), the substrate and the habitat types (palsa, fen, bedrock plateau, valley, flood plain, slope, flat terrain wetlands, dry land or raised beach).

The dominant tree species in the region is black spruce ( $P$. mariana), which grows as krummholz, isolated trees or small wooded stands near Umiujaq; larger wooded stands are found to the south and southeast of the study site. Larix laricina is found near Lac Guillaume-Delisle and $P$. glauca appears at the coast. The dominant species of erect shrubs are, in order of importance, Betula glandulosa, Salix planifolia, S. glauca, Rhododendron groenlandicum and Alnus crispa (Brouillet et al., 2010). The vegetation height ranges up to $3 \mathrm{~m}$. The surface cover was classified as tall vegetation $(>50 \mathrm{~cm}$, including spruce and tall shrubs), low shrubs $(<50 \mathrm{~cm})$, low vegetation (including lichens, prostrate shrubs and herbaceous vegetation), rock, gravel and sand (non-vegetated), or water. These groups were also used as a basis for classifications from the satellite imagery.

The correlation between land cover changes and permafrost dynamics was investigated on the basis of six field campaigns conducted between April 2009 and October 2010, which recorded the active layer thickness (ALT) for different vegetation habitats at 100 sites spread across the study area. For these depth estimates, a rod of galvanised steel $200 \mathrm{~cm}$ long, equipped with a thermometer and a depth measurement scale, was inserted into the ground to record temperatures and ALT. The top of the frozen ground was assumed to have been reached when the resistance was too great to permit any further penetration. In order to avoid misinterpretation due to obstruction by rocks, the soil temperature was also required to reach $0^{\circ} \mathrm{C}$. This method was validated by digging several holes into the active layer until frozen ground was encountered. Snow cover was recorded at the same sites during winter (April 2009, March 2010,
May 2010), to investigate the relationship between vegetation type, ALT and snow cover.

Since the purpose of the field data was also to serve as reference material for the vegetation classification, the field sites were chosen to provide an equal representation of each different vegetation type, which was also recorded during the field campaigns.

\section{Analysis of Time Series of Remote Sensing Data}

The ERDAS IMAGINE (ERDAS, Earth Resource Data Analysis System, Atlanta, Georgia, USA) image processing software was used to process and analyse the optical remote sensing data, and additional appraisals were carried out using ArcGIS version 9.1 (ESRI, Munich, Bavaria, Germany) software. The images were all delivered geometrically corrected in UTM coordinates (Zone $18 \mathrm{~N}$ in the world geodetic system, WGS 84).

Haze reduction was applied to all images for radiometric correction. This method (also known as dark subtraction) is based on the hypothesis that in every image at least one of the pixels will have zero reflectance (Gomarasca, 2004). Image enhancement in the form of a histogram stretch was applied to the QuickBird scene as the original was very low contrast for visual analysis. The aim of a histogram stretch is to improve the image's contrast by transforming each digital number in the original image into a specific grey value in the displayed image by means of a specific mapping function (Schowengerdt, 1997).

A classification based on the field data was applied to the images, followed by the application of two change detection techniques.

\section{Classification}

The classification was required in order to be able to compartmentalise any observed changes. A two-step approach was chosen for the classification: the Iterative Selforganising Data Analysis Algorithm was implemented as an unsupervised classification, followed by a supervised classification using the Maximum-Likelihood Algorithm. 
This is a common procedure in which the image is first roughly classified by the unsupervised method and then the results are refined by a supervised classification (Aronoff, 2005). The ground cover was classified as tall vegetation, low shrubs, low vegetation, non-vegetated or water, based on the vegetation groups used during the field programmes. An accuracy assessment of the classification outcomes was conducted following the methodology of Gopal and Woodcock (1994).

\section{Classification Problems and Accuracy}

The classification was carried out successfully on four images (Landsat 1986 and 2008, QuickBird 2004 and GeoEye 2009), validated using the accuracy assessment methods. The only problems encountered were due to snow patches or pixels concealed by cloud cover in the Landsat scenes of 1990, 2001 and 2008, which in most cases resulted in incorrect classification. In order to reduce the number of such errors, masks were generated to exclude the affected pixels. The areas were therefore initially roughly mapped manually and then improved by means of band 6 (thermal band $10.4-12.5 \mu \mathrm{m})$. About 20 per cent of the image from 2008 was then masked out, but half of this masked region was classified as water area (Hudson Bay) and is not important for the purpose of this study. Unfortunately, the masked areas in Landsat images from 1990 and 2001 were too large to allow satisfactory and meaningful classification results to be achieved, and hence they were excluded from the change detection by means of Postclassification Analysis.

Assessing the accuracy of the classification results and identifying the reasons for any errors were important in order to optimise the results and assess their reliability (Gopal and Woodcock, 1994). The accuracy assessment involved the validation of a sample of classified pixels for which the land cover was known from the field surveys. Through this comparison, the overall accuracy (i.e. the proportion of correctly classified pixels) was calculated for each of the classified images. The kappa coefficient, which indicates the percentage of correctly allocated pixels (as confirmed by field records), was also applied (Congalton and Green, 1999). It yielded values between 0 and 1, where 1 represents 100 per cent correct allocation. Both the overall accuracy for each classification and the kappa coefficient were calculated for each image, yielding satisfactory results with overall accuracies greater than 90 per cent in every case and kappa coefficients greater than 0.9 (Table 2). Detailed accuracy assessment is discussed in the Classification section of the Results and Discussion.

\section{Change Detection}

Change detection was applied separately to the four Landsat images and the two high-resolution images. Using the available data, May (2011) applied four different change detection methods to this study area: Postclassification Analysis, Tasselled Cap Transformation (Kauth and Thomas, 1976), Write Memory Insertion (Grey et al., 1998) and Index Differencing (Koeln and Bissonnette,
2000), which identified Postclassification Analysis and Index Differencing as being the most suitable. The Tasselled Cap Transformation yielded questionable results, probably because it was developed to follow vegetation development during a particular season rather than to detect changes in plant species. The Write Memory Insertion technique provided a useful visualisation tool for the changes but yielded no quantitative data.

Postclassification Analysis is based on two independently produced spectral classification results from two different dates, followed by a pixel-by-pixel comparison to detect any changes in the land cover type. By properly coding the classification results, the outcome is a complex matrix of change (Coppin et al., 2002). Although this method has often been criticised because of its absolute dependency on the accuracy of the classification, satisfactory examples of its use have been provided by Xu and Young (1990) and Hall et al. (1991), and hence the method was also used for this study. Our results derived from the Postclassification Analysis method are considered to be valid, given the high classification accuracies (see Table 3).

Index Differencing was used to combine the radiometric pixel value with its temporal comparison. Typical combinations result in specific indices (Tansey, 2006) that represent the state of the vegetation at a particular moment in time. Computing indices for different dates allow changes in these indices to be compared.

The NDVI is a measure of relative greenness that was first developed for use with AVHRR data, and is calculated as follows:

$$
\mathrm{NDVI}=(\mathrm{NIR}-\mathrm{Red}) /(\mathrm{NIR}+\mathrm{Red})
$$

NIR is the spectral reflectance in the NIR (where reflectance from the plant canopy is dominant), and Red is the reflectance in the red portion of the spectrum (where the absorption by chlorophyll is at its maximum). The resulting NDVI can theoretically reach values between -1 and 1 , where -1 represents no vegetation cover and 1 represents a very dense and active vegetation cover (Bellward, 1991).

For the change detection, the NDVI had first to be individually defined for each of the images before any differences could be identified. It is important to be aware, however, of the uncertainties involved in this method when used for the analyses in this study, as the index only represents the current status of the phenology at the time of

Table 2 Overall accuracy (\%) and kappa coefficients as values for the classification quality, for the four classified images Landsat 1986 and 2008, QuickBird 2004 and GeoEye 2009.

\begin{tabular}{lcc}
\hline Satellite & Overall accuracy [\%] & Kappa coefficient \\
\hline Landsat (1986) & 95 & 0.90 \\
Landsat (2008) & 98 & 0.94 \\
QuickBird (2004) & 90 & 0.90 \\
GeoEye (2009) & 92 & 0.90 \\
\hline
\end{tabular}




\section{Beck et al.}

Table 3 User's (first column) and producer's (second column) accuracies (\%) for each of the five classified land cover types, shown for the four classified images Landsat 1986 and 2008, QuickBird 2004 and GeoEye 2009.

\begin{tabular}{|c|c|c|c|c|c|c|c|c|c|c|}
\hline & \multicolumn{2}{|c|}{ Tall vegetation } & \multicolumn{2}{|c|}{ Low shrubs } & \multicolumn{2}{|c|}{ Low vegetation } & \multicolumn{2}{|c|}{ Non-vegetated } & \multicolumn{2}{|c|}{ Water } \\
\hline \multicolumn{11}{|c|}{ First number: User's accuracy [\%]; Second number: Producer's accuracy [\%] } \\
\hline Landsat 1986 & 99 & 98 & 99 & 99 & 97 & 98 & 98 & 97 & 98 & 90 \\
\hline Landsat 2008 & 98 & 99 & 98 & 98 & 98 & 99 & 94 & 76 & 69 & 92 \\
\hline QuickBird 2004 & 82 & 74 & 95 & 88 & 95 & 100 & 100 & 75 & 92 & 99 \\
\hline GeoEye 2009 & 85 & 98 & 100 & 99 & 88 & 98 & 88 & 98 & 98 & 100 \\
\hline
\end{tabular}

the image acquisition. The NDVI can therefore not be used as a stand-alone approach for such studies, which is why we used it in conjunction with the Postclassification Analysis.

\section{Mapping of Thermokarst Lakes and Lithalsas}

In order to address the development of thermokarst lakes and lithalsas, we manually inspected and digitised these features from the satellite images in ten sub-areas (between $400 \mathrm{~m}^{2}$ and $5000 \mathrm{~m}^{2}$ ) using ArcGIS (Figure 2). These sub-areas were selected to include both features and to be well distributed over the study site. Since the spatial resolution of the Landsat scenes was insufficient to allow the identification of individual features, only the QuickBird 2004 and GeoEye 2009 images were used.

\section{RESULTS AND DISCUSSION}

\section{Classification}

The image classifications revealed a marked difference between the images with a low spatial resolution (Landsat) and those with a high resolution (QuickBird, GeoEye). In particular, the areas of water cover were underestimated in the Landsat images: a comparison between the Landsat image from 2008 and the GeoEye image from 2009 over two areas, one in the coastal region and one in the Lac Guillaume-Delisle graben (combined area $10.5 \mathrm{~km}^{2}$ ), showed $1.25 \mathrm{~km}^{2}(11.9 \%)$ less area classified as water in the Landsat scene. Water bodies with surface areas of less than $3600 \mathrm{~m}^{2}$ could generally not be detected at the lower spatial resolution, whereas with the high-resolution data we were able to map thermokarst lakes (which were of

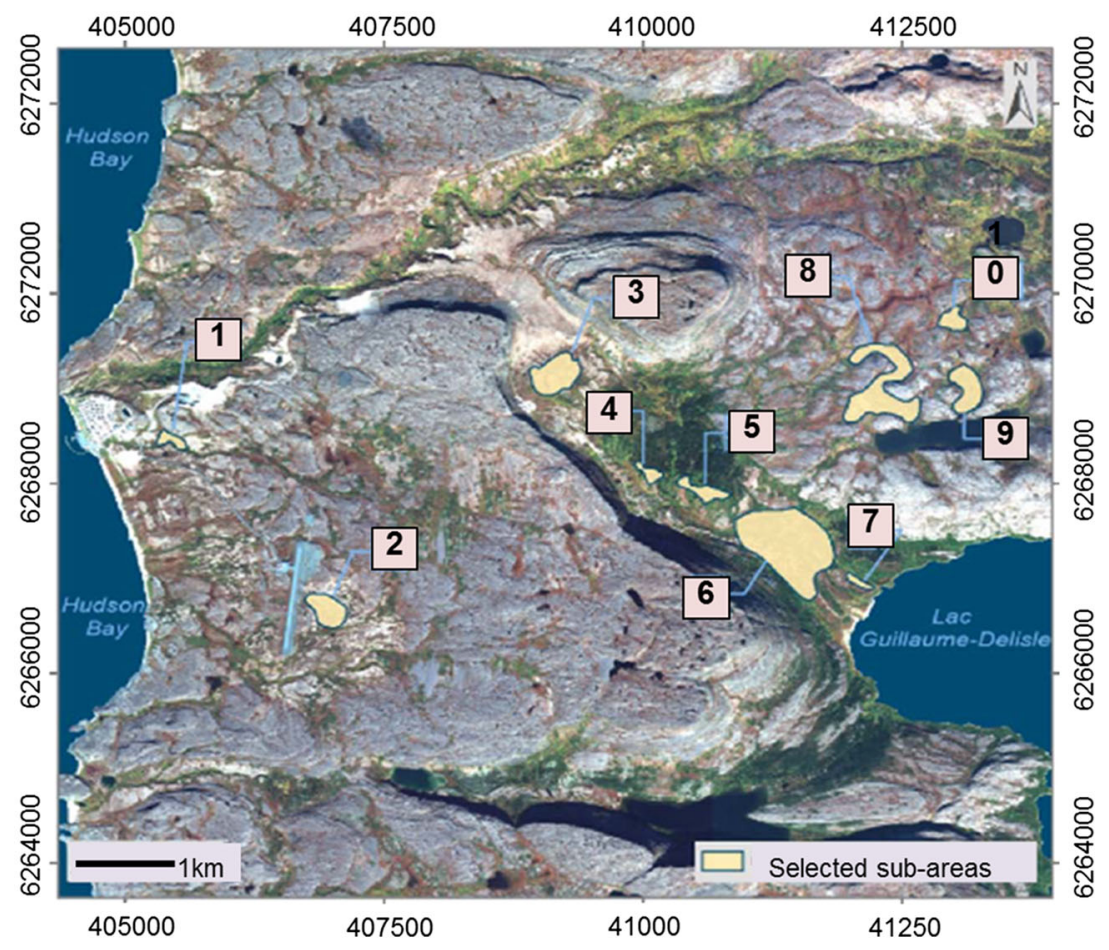

Figure 2 Overview of the ten selected sub-areas within the study site around Umiujaq, sub-Arctic Quebec, in which lithalsas and thermokarst ponds were mapped manually from satellite images. In the background, the GeoEye image of 2009 is given in UTM coordinates. This figure is available in colour online at wileyonlinelibrary.com/journal/ppp 
major interest in this study) with an average size of $234 \mathrm{~m}^{2}$. These outcomes were also confirmed by the accuracy assessments for each land cover type (Table 3 ). The producer's accuracy (pixels that were incorrectly excluded from a class) for water was less in the Landsat images (90\% 1986; 92\% 2008) than in the high-resolution images (99\% 2004; 100\% 2009). Their existence was therefore ignored in the Landsat image classifications. Because of these discrepancies caused by the different image resolutions, separate change detection analyses were conducted for the low-resolution images and the high-resolution images.

\section{Change Detection}

\section{Vegetation Changes}

The Postclassification Analysis of the Landsat classifications (1986 and 2008) showed an overall increase in vegetation extent. In the Lac Guillaume-Delisle graben, the expansion of the 'tall vegetation' class was particularly dominant, whereas the 'low shrubs' cover increased along the Hudson Bay coastline and in protected valley habitats.

In order to obtain a quantitative estimate of the changes in vegetation cover, we calculated the percentages of each type of land cover for 1986 and 2008 (Figure 3). This revealed increases in 'tall vegetation' cover $(+10 \%)$ and 'low shrubs' cover $(+6 \%)$, with an associated distinct reduction in 'low vegetation' cover $(-16 \%)$. The higher value obtained for 'non-vegetated' cover in $2008(+3 \%)$ is attributed to an increase in the area of construction sites, characterised by gravel and rocks.

An interannual NDVI comparison supported the results from the Postclassification Analysis, since the NDVI was computed to have decreased by 3.2 per cent between 1986 and 1990. This can be explained by the fact that the 1990 image was acquired later in the year (2 August) than the 1986 image (1 July). Other NDVI studies in the Arctic and sub-Arctic, such as those of Jia and Epstein (2004) in Alaska or Pettorelli et al. (2005) in northern Norway, found that the peak in the growing season in these areas occurred in the middle of July, followed by a rapid decrease in the NDVI. The NDVI would therefore be expected to be lower

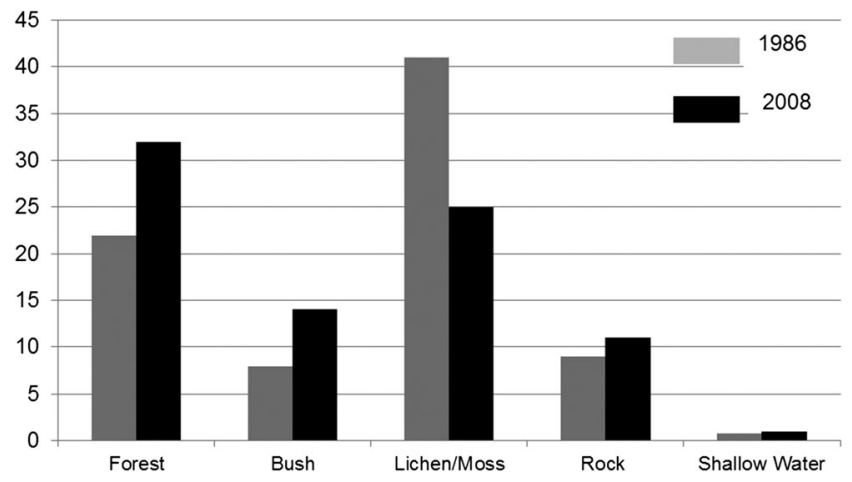

Figure 3 Proportion of the analysed area in the Landsat imagery $\left(\sim 3.5 \mathrm{~km}^{2}\right.$ near Umiujaq, sub-Arctic Quebec) covered by the five land cover classes in 1986 and 2008, using Postclassification Analysis. in August than in July. The NDVI increased by 3.3 per cent over the subsequent years from 1990 to 2001 and by 7 per cent during the last 7 year period (2001-08). The total development of the NDVI over the entire time period (1986-2008) showed a strong (>10\%) increase, suggesting an increase in the density of green leaves (NASA, 2000).

The spatial distribution of the changes recorded between 1986 and 2008 showed that most of the vegetation recruitment occurred near Lac Guillaume-Delisle and in the wind shadows of the cuestas.

High-resolution change detection based on QuickBird and GeoEye imagery confirmed the trends detected over the long time series of the Landsat data. Postclassification Analysis of the high-resolution data highlighted the fact that the vegetation cover increased between 2004 (QuickBird) and 2009 (GeoEye), with the greatest increases occurring within the Lac Guillaume-Delisle graben. 'Tall vegetation' appeared to take over areas that had previously been dominated by 'low vegetation', while 'low vegetation' took over areas previously classified as 'non-vegetated' and 'water' (Figure 4).

A large increase $(+21 \%)$ was observed in the area covered by the 'tall vegetation' class, together with a decrease in the 'low shrubs' $(-4 \%)$, 'non-vegetated' (-4\%) and 'water' $(-2 \%)$ classes; the proportion of 'low vegetation' remained almost unchanged. A more detailed analysis revealed that most of the decrease occurred in the 'low shrubs' class, with these being replaced by 'tall vegetation'.

The NDVI was also calculated for 2004 and 2009. To visualise the change in vegetation between these 2 years, we divided the NDVI values into the following classes: pixels with negative NDVI values had no vegetation, while those with values of $0-0.2,0.2-0.4,0.4-0.6$ and $0.6-0.8$ represented increasing 'greenness' of vegetation, with the last class representing very vigorous vegetation. Figure 5. shows a histogram based on these classes: a decrease in non-vegetated and less vegetated areas can be seen between 2004 and 2009 as well as an increase in moderate and vigorous vegetation. The mean NDVI in 2004 was 0.24 , whereas it was 0.35 in 2009.

Any interpretation of these findings needs to take into account that the 2009 image was recorded 2 months later (late

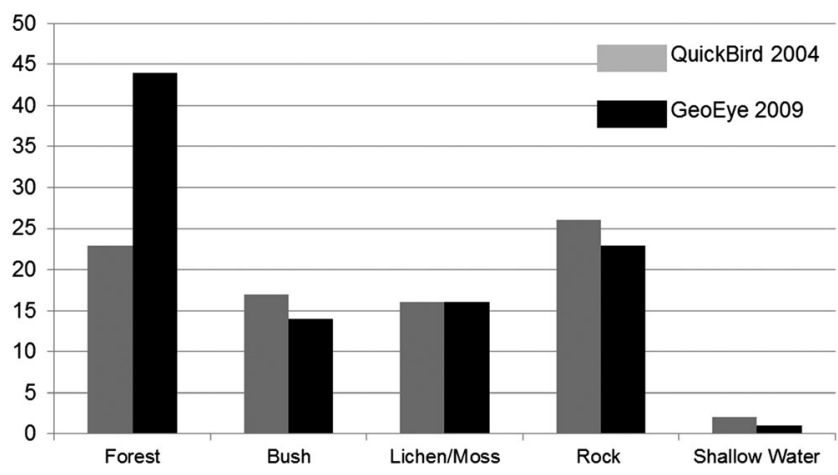

Figure 4 Proportion of the analysed area in the QuickBird and GeoEye images $\left(\sim 15 \mathrm{~km}^{2}\right.$ near Umiujaq, sub-Arctic Quebec) covered by the five land cover classes in 2004 and 2009. 


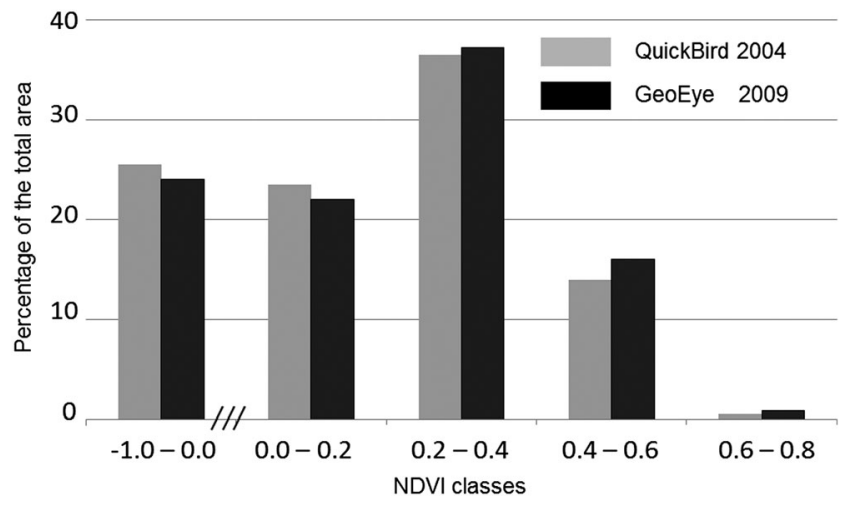

Figure 5 Histogram of calculated normalised difference vegetation index (NDVI) values for the study area (Umiujaq, sub-Arctic Quebec) for 2004 and 2009, based on the defined NDVI classes (with $<0$ representing no vegetation and $0-0.2,0.2-0.4,0.4-0.6$ and $0.6-0.8$ representing increasing vegetation intensity).

September) than the 2004 image (July), and a reduced NDVI would therefore be expected. The fact that the results show the opposite effect suggests that there may have been an even greater difference between the NDVIs for July 2004 and July 2009.

Records of the ALT from a number of different vegetation habitats were taken into account to allow the observed changes in vegetation to be used as indicators of permafrost dynamics: taller vegetation was clearly associated with greater snow depths, as has also been indicated by other investigations into snow accumulation (Ménard et al., 1998; Allard et al., 1993).

The ALT measured beneath different heights of vegetation showed a heterogeneous small-scale pattern that correlated with the land cover type. The ALT was similar for 'tall vegetation' and 'low shrubs', but slightly less for 'low vegetation'. Areas with vegetation taller than $50 \mathrm{~cm}$ corresponded to an ALT of between 141 and $190 \mathrm{~cm}$, with the only exception being a single 'tall vegetation' site with an ALT of $120 \mathrm{~cm}$; at all other sites an ALT of at least 141 $\mathrm{cm}$ was measured (Figure 6). Measurement sites with no vegetation often had an ALT of no more than $5 \mathrm{~cm}$ (data not shown) and very variable snow depths $(0-150 \mathrm{~cm}$, depending on the influence of the wind), demonstrating that the insulating effect of snow cover is not the sole influence on the ALT, but that other factors also need to be taken into account. For example, Beringer et al. (2001) described the insulating effect of bryophytes (mosses, liverworts, hornworts), and Langer et al. (2013) suggested that soil texture (a sand-silt mixture at the particular site investigated) and ice content had a major influence on thaw depth.

Other investigations in North America have shown results that are similar to our own. For example, Clebsch and Shanks (1968), Mackay (1974), Romanovsky and Osterkamp (1995) and Nelson et al. (1997) have all stated that the summer temperatures in north Alaska control the development of vegetation communities, which in turn

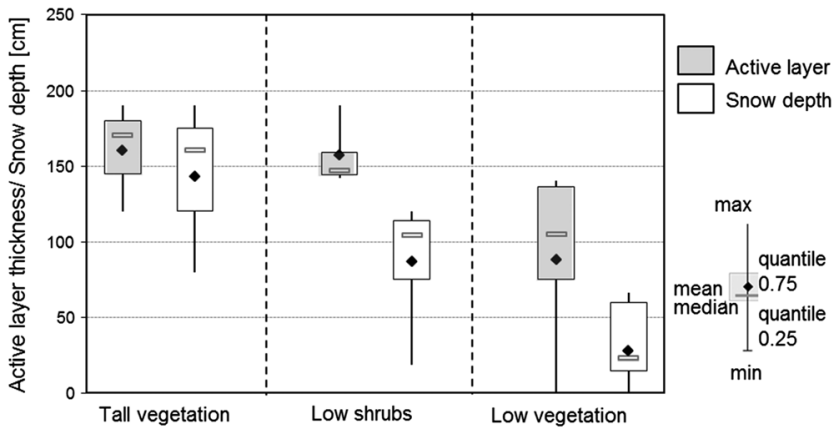

Figure 6 Active layer thickness $(\mathrm{cm})$ was measured in August 2009 and 2010 and snow depth $(\mathrm{cm})$ in April 2009 and March 2010 in areas with three different vegetation types: tall vegetation $(n=30)$, low shrubs $(n=10)$ and low vegetation $(n=30)$ near Umiujaq, sub-Arctic Quebec.

affect snow accumulation, near-surface ground temperatures and active layer development.

\section{Thermokarst Lakes and Lithalsas}

The analysis of low-resolution Landsat imagery revealed only minor changes in the surface areas of the water bodies, and was not able to detect any lithalsas at all. Between 1986 and 2008 , an increase of 0.4 per cent $\left(7.3 \mathrm{~km}^{2}\right)$ was recorded in the total surface area covered by water bodies (based on Postclassification Analysis). The low resolution of these images clearly limits their ability to show small features and these results should therefore clearly be treated with caution since the classification results revealed that the image resolution of the Landsat data was too low to adequately detect all water bodies. Similar results were obtained by Muster et al. (2013), who reported an underestimation of the surface area covered by water of up to 90 per cent. Lyons et al. (2013) also indicated spatial errors in Landsat-based lake mapping, tested on the Arctic Coastal Plain of Alaska.

Manual mapping of water bodies from Landsat images was only possible for lakes larger than approximately $3600 \mathrm{~m}^{2}$, as was evident from a comparison between the results achieved and those obtained from the high-resolution imagery. The lithalsas could not be identified from the Landsat data and were therefore not mapped manually from this imagery.

Manual mapping of the thermokarst lakes from highresolution satellite images in the ten selected sub-areas (Figure 2) identified 531 lakes from the 2004 (QuickBird) imagery (total area $135000 \mathrm{~m}^{2}$ ) and 483 lakes from the 2009 (GeoEye) imagery (total area $102000 \mathrm{~m}^{2}$ ) (Table 4). The average size of the lakes decreased during this period from $254 \mathrm{~m}^{2}$ to $211 \mathrm{~m}^{2}$. The total size of water bodies in the ten sub-areas decreased by approximately 24 per cent $\left(33000 \mathrm{~m}^{2}\right)$ between 2004 and 2009; only in the most eastern sub-areas $(8,9$ and 10) were any new lakes formed. The reduction in the area covered by water was particularly marked in sub-area 2 (Figure 2; Table 4), with 17 lakes disappearing completely and the remainder losing 50 per 
cent of their surface areas; no new lakes were formed in this area. Reductions in the areas covered by water were also observed at all other sites, ranging from 5 per cent in sub-area 10 to 34 per cent in sub-area 6 .

Interestingly, our results are in contrast to the expansion of thermokarst lakes previously recorded, for example, the 44 per cent increase in area recorded by Laprise and Payette (1988) in their study east of Umiujaq. The large reduction in the area covered by water that we observed in sub-area 2 (Figure 2) may be due to altered hydrology around the airport.

Because the 2009 image was acquired 2 months later in the year than the 2004 image a deeper active layer may have resulted in increased drainage from the lakes, which might explain the reduction in water areas. However, such a reduction is unlikely to be solely due to changes in the drainage system and is probably also related to regional changes in the water budget. Many investigations have been carried out into the disappearance of lakes, often with contradictory results (e.g. Smith et al., 2005; Kravtsova and Bystrova, 2009). Boike et al. (2013), for example, found that thermokarst lakes in a Siberian catchment were strongly dependent on precipitation and evapotranspiration, and on the annual water balance.

It is therefore important to take into account the water budget for the two investigated years. The only difference between the annual water balances for 2004 and 2009 and the average over a longer period (1977-2010) is in the total precipitation, which was $682 \mathrm{~mm}$ in 2004, $663 \mathrm{~mm}$ in 2009 and $574 \mathrm{~mm}$ averaged over 1977-2010. The values for 2004 and 2009 are very similar to the long-term average (672 $\mathrm{mm}$ ) over the more recent period from 2001 to 2010. These two precipitation averages (1977-2010 and 2001-10) reveal an increase in precipitation within the study area. A more detailed analysis of the monthly totals reveals that the summer months (June, July and August) were relatively wet $(250 \mathrm{~mm})$ in 2004 compared to both $2009(220 \mathrm{~mm})$ and the average for 2001-10 (221 mm) (Figure 7). Runoff data from the nearby Sheldrake River (Figure 1) are only

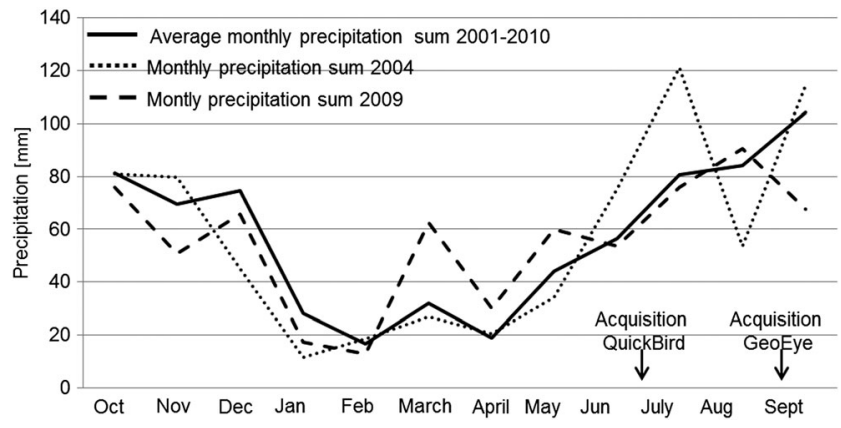

Figure 7 Average long-term (10 years) monthly precipitation sums and monthly precipitation sums for 2004 and 2009 at Umiujaq, sub-Arctic Quebec (based on data from the climate station at Kuujjuarapik: N55 16.587, W77²4.775).

available from 2009 and hence additional information concerning the water budget is only available for that year. During 2009, a mean runoff of $17 \mathrm{~m} / \mathrm{s}$ was recorded between break-up and freeze-up, which is almost identical to the mean value for 2009-13 of $16.8 \mathrm{~m} / \mathrm{s}$ (Jolivel, 2014). These data therefore suggest that the water budget in 2009 was typical for the area.

Although Figure 7 highlights a very wet July $(121 \mathrm{~mm})$ in 2004 (the month of the QuickBird image acquisition) compared to September $(89 \mathrm{~mm}) 2009$ (the month of the GeoEye image acquisition), an analysis of the daily precipitation totals shows that the high precipitation in July 2004 resulted from a single heavy rainfall event that occurred after the acquisition date of the QuickBird image (11 July), and since only $9.4 \mathrm{~mm}$ of rain was recorded up to the 11 July the image does not reflect the very wet July. In addition, no rain at all was recorded for the 4 days immediately prior to the image acquisition (7-10 July). In contrast, most $(84 \%)$ of the rainfall measured in September 2009 preceded the acquisition date of the GeoEye image (24 September).

If we compare the precipitation totals for the last 7 days prior to the image acquisitions, less than half the amount

Table 4 Overview of the area (in $1000 \mathrm{~m}^{2}$ ) lakes and lithalsas and the number of manually mapped lakes and lithalsas (from highresolution satellite images) within the study area (near Umiujaq, sub-Arctic Québec) in 2004 and 2009.

\begin{tabular}{|c|c|c|c|c|c|c|c|c|c|c|}
\hline \multirow{3}{*}{$\begin{array}{l}\text { Site } \\
1\end{array}$} & \multicolumn{4}{|c|}{$\begin{array}{c}2004 \text { (QuickBird) } \\
\text { (area in } 1000 \mathrm{~m}^{2} / \text { number) }\end{array}$} & \multicolumn{4}{|c|}{$\begin{array}{c}\mathbf{2 0 0 9}(\mathbf{G e o E y e )} \\
\text { (area in } 1000 \mathrm{~m}^{2} / \text { number) }\end{array}$} & \multicolumn{2}{|c|}{$\begin{array}{c}\mathbf{2 0 0 4}-\mathbf{2 0 0 9} \\
\text { (changes in } 1000 \mathrm{~m}^{2} \text { ) }\end{array}$} \\
\hline & \multicolumn{2}{|c|}{ lakes } & \multicolumn{2}{|c|}{ lithalsas } & \multicolumn{2}{|c|}{ lakes } & \multicolumn{2}{|c|}{ lithalsas } & \multirow{2}{*}{$\begin{array}{r}\text { Lakes } \\
-0.2\end{array}$} & \multirow{2}{*}{$\begin{array}{r}\text { lithalsa: } \\
-0.5\end{array}$} \\
\hline & 1.4 & 17 & 2.8 & 3 & 1.2 & 14 & 2.3 & 3 & & \\
\hline 2 & 15.7 & 32 & 2.0 & 1 & 7.8 & 17 & 2.0 & 1 & -7.9 & -0.0 \\
\hline 3 & 13.2 & 91 & 66.2 & 18 & 9.5 & 59 & 64.7 & 18 & -3.7 & -1.5 \\
\hline 4 & 2.7 & 21 & 7.0 & 4 & 2.3 & 21 & 6.2 & 4 & -0.4 & -0.8 \\
\hline 5 & 2.1 & 17 & 16.5 & 10 & 1.6 & 16 & 15.6 & 11 & -0.5 & -0.9 \\
\hline 6 & 39.8 & 155 & 95.2 & 30 & 26.4 & 154 & 90.0 & 32 & -13.4 & -4.3 \\
\hline 7 & 1.7 & 9 & 2.6 & 2 & 0.4 & 4 & 2.2 & 2 & -1.2 & -0.3 \\
\hline 8 & 40.7 & 88 & 91.0 & 25 & 37.5 & 95 & 84.3 & 29 & -3.2 & -6.8 \\
\hline 9 & 14.1 & 71 & 3.0 & 7 & 11.8 & 73 & 1.6 & 3 & -2.3 & 1.4 \\
\hline 10 & 3.6 & 30 & 7.6 & 9 & 3.4 & 30 & 6.4 & 9 & -0.2 & -1.2 \\
\hline Total & 135 & 531 & 293.9 & 109 & 102 & 483 & 276.1 & 112 & -33 & -17.8 \\
\hline
\end{tabular}


of water was available in 2004 (6 mm) compared to 2009 (17 mm).

To investigate further the hypothesis that the decrease in the area covered by thermokarst lakes was a result of advanced permafrost degradation, we visually inspected the ten sub-areas in two high-resolution images (an IKONOS image acquired in July 2005 and aerial photographs acquired in August 2010, data not shown). These images, however, were not used in this study as they did not meet the requirements with respect to spectral resolution and were therefore not appropriate for the vegetation comparisons. The surface area covered by water hardly changed between 2004 and 2005, even though the precipitation in 2005 was close to average (annual precipitation $663 \mathrm{~mm}$ ), and there was less surface water detected in the air photographs from 2010 (annual precipitation $661 \mathrm{~mm}$ ) than in the images from 2004 and 2005. The results of this analysis therefore support the hypothesis of disappearing thermokarst lakes. The change from increasing to decreasing areas of surface water within the study area in recent years is also confirmed by the results of the Landsat classifications, which showed an increase between 1986 and 2008.

The fact that new lakes formed in 2009 in sub-areas 8, 9 and 10 can be explained by the location of the lakes on the margins of lithalsas (Figure 8). As discussed, such frost mounds experienced a decrease in area between 2004 and 2009. Collapsing lithalsas often produce small lakes at the foot of their margins due to subsidence and melting ice cores, a phenomenon that was also observed by Calmels et al. (2008). In the case of the newly developed lakes, this fact probably overrides the water deficit. This suggests that permafrost thaw may have reached a new degree in this area, in which newly formed lakes disappear again due to drainage and the loss of a water source (since all frozen ground has thawed), and vegetation starts to colonise the lake margins.

The total area covered by lithalsas decreased by about 6 $\%$ between 2004 and 2009, from $0.29 \mathrm{~km}^{2}$ to $0.27 \mathrm{~km}$, with the highest rate of decrease occurring in the Lac Guillaume-
Delisle graben. A decrease in the total area covered by lithalsas had previously been noted (up to 2005) from field measurements in the area (Fortier and Aubé-Maurice, 2008); this led to the collapse of frost mounds and has been attributed to higher MAGTs.

This study also revealed three new mounds (2004 total: 109; 2009 total: 112) but these resulted from the splitting up of a single larger mound, possibly indicating a process of collapse. The degradation process observed in the past appears to be continuing and correlates with the ongoing increase in MAGTs measured by Fortier et al. (2011). Monitoring of palsa degradation in various studies (e.g. Calmels et al., 2008; Laberge and Payette, 1995; Seppälä, 1988) has shown that degradation is greatly influenced by air temperature, depth of snow cover and the insulating peat layer (Brown, 1968; Zoltai and Tarnocai, 1971). Palsa degradation is therefore accepted as a good indicator of climatic changes (Fronzek et al., 2006; Luoto et al., 2004).

The presented study has shown that, in a sub-Arctic transition zone such as the study area, permafrost thaw is occurring due to changing environmental conditions and is already quite advanced. The thawing of permafrost has been monitored by means of multi-scale remote sensing data, from which surface features have been identified that reflect the state of the underlying permafrost. The correlation between these features and the permafrost has been confirmed by field measurements. The results enhance the findings of previous studies (e.g. Allard and Séguin, 1985, 1987; Laberge and Payette, 1995; Fortier and Aubé-Maurice, 2008) that have indicated the high sensitivity of this area to climate change.

Our results, however, suggest that this region has now reached a tipping point between two levels of permafrost degradation. This new hypothesis is based on the fact that the newly created thermokarst lakes observed in the past are now rapidly disappearing. This disappearance can be explained by increased drainage, the loss of a water source and colonisation of the lake margins by vegetation.
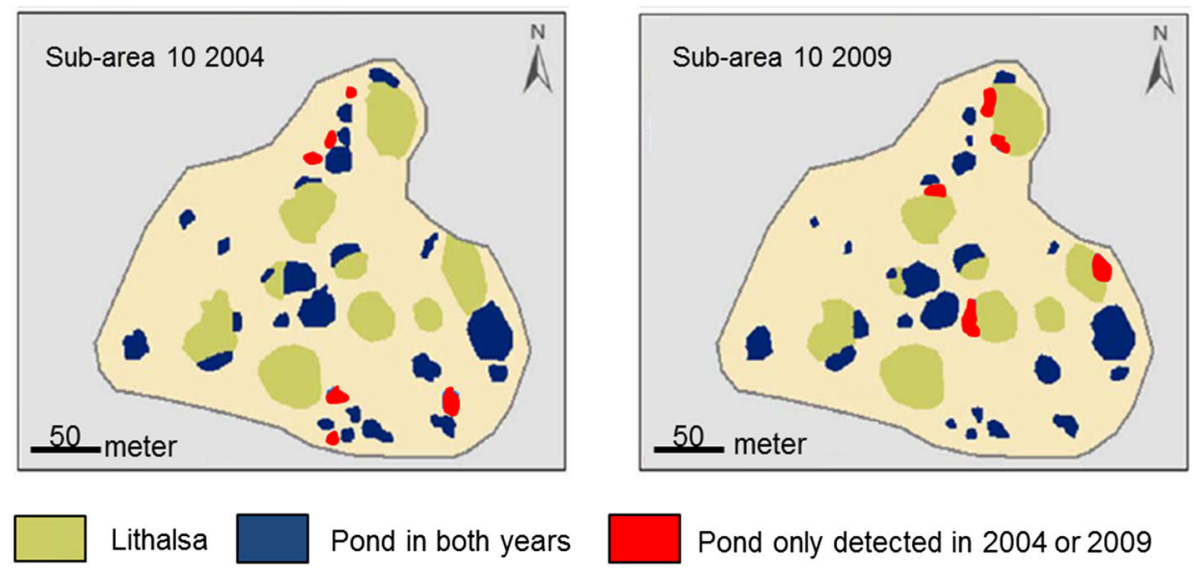

Pond only detected in 2004 or 2009

Figure 8 Changes in thermokarst ponds and lithalsas within sub-area 10 (Figure 2) - shown as an example (mapped manually from the QuickBird 2004 and GeoEye 2009 images). This figure is available in colour online at wileyonlinelibrary.com/journal/ppp 
Our investigations have also illustrated a possible method for detecting the state of permafrost from space, and also detecting the wetting or drying of the Earth's surface between one image and another using high-resolution data. Such information is not available from low-resolution data.

\section{CONCLUSION}

From this investigation of land cover changes (i.e. changes to vegetation, water bodies and lithalsas) observed in Umiujaq, sub-Arctic Québec, by means of satellite images, we are able to draw the following conclusions:

1. Landsat images and high-resolution (QuickBird, GeoEye) images provide valuable information about vegetation changes, but only high-resolution data are able to adequately reveal small water bodies and lithalsas.

2 . The extent of vegetation cover has increased between 1986 and 2009, and lithalsas have been collapsing between 2004 and 2009. These processes are likely to have been stimulated by a warming climate.

3. Whereas earlier studies have highlighted an increase in the number and area of thermokarst lakes, our study has revealed a decreasing area covered by water bodies.
Such lake drainage indicates a new phase in the development of thermokarst lakes.

4. Future work should focus on time series of highresolution remote sensing data to detect, quantify and confirm the observed changes across the sub-Arctic.

\section{ACKNOWLEDGEMENTS}

We thank the community of Umiujaq for their support and Benoît Tremblay, Mathieu Leblanc and Vincent Lamarre for the vegetation survey work. Special thanks go to the two Ludwig-Maximilians University students, Kathrin Einzmann and Alexander Strehmel, for their assistance. We gratefully acknowledge the financial support provided by ArcticNet (the Natural Sciences and Engineering Council of Canada (NSERC) Network of Centers of Excellence), the Deutsche Forschungsgesellschaft, the European Union FP7-ENV PAGE21 (Changing Permafrost in the Arctic and its Global Effects in the 21st Century) project under contract number GA282700 and the Arctic Development and Adaptation to Permafrost in Transition programme. We also would like to thank the reviewers for their helpful comments and constructive criticism.

\section{REFERENCES}

Åkerman HJ, Johansson M. 2008. Thawing permafrost and thicker active layer in sub-arctic Sweden. Permafrost and Periglacial Processes 19: 279-292. DOI: 10.1002/ppp.626

Allard M, Séguin MK. 1985. La déglaciation d'une partie due versant hudsonien Québécois: Bassin des rivières Nastapoca, Sheldrake et à l'Eau Claire. Géographie Physique et Quaternaire 39(1): 13-24.

Allard M, Séguin MK. 1987. Le pergélisol au Québec nordique: bilan et perspectives. Géographie Physique et Quaternaire 41(1): 141-152.

Allard M, Tremblay C, Pilon JA, Frydericki J. 1993. Quarternary geology and geocryology in Nunavik, Canada. In Proceedings ${ }^{\text {th }}$ International Conference on Permafrost, Beijing, China. South China University of Technology Press: Beijing; 5-10.

Allard M, Fortier R, Sarrazin D, Calmels F, Fortier D, Chaumont D, Savard JP, Tarussov A. 2007. L'impact du réchauffement climatique sur les aéroports du Nunavik: caractéristiques du pergélisol et caratérisation des processus de dégradation des pistes. Sommaire Project A803. University Laval, Ouranos, Canada.

Aronoff S. 2005. Remote Sensing for GIS Managers. ESRI Press: Redland, CA.

Bellward AS. 1991. Remote Sensing and Geographical Information Systems for
Resource Management in Developing Countries, 1. Kluwer Academic Publishers for the Commission of the European Communities.

Beringer J, Lynch AH, Chapin FS, Mack M, Bonan GB. 2001. The representation of arctic soils in the land surface model: the importance of mosses. Journal of Climate 14: 3324-3335.

Boike J, Kattenstroth B, Abramova K, Bornemann N, Chetverova A, Fedorova I, Fröb K, Grigoriev M, Grüber M, Kutzbach L, Langer M, Minke M, Muster S, Piel K, Pfeiffer EM, Stoof G, Westermann S, Wischnewski K, Wille C, Hubberten HW. 2013. Baseline characteristics of climate, permafrost and land cover from a new permafrost observatory in the Lena River Delta, Siberia (1998-2011). Biogeosciences 10: 2105-2128. DOI:10. 5194/bg-10-2105-2013.

Brouillet L, Coursol F, Meades SJ, Favreau M, Anions M, Bélisle P, Desmet P. 2010. VASCAN, the Database of Vascular Plants of Canada. http://data.canadensys.net/ vascan/ [15 December 2014].

Brown RJE. 1968. Occurrence of permafrost in Canadian peatlands. In Proceedings of the Third International Peat Congress, Lafleur C, Butler J (eds). National Research Council of Canada: Ottawa; A174-A181.

Calmels F, Delisle G, Allard M. 2008. Internal structure and thermal and hydrological regime from three boreholes temperature profiles in northern Québec. Canadian Journal of Earth Sciences 45(1): 31-43.

Clebsch EEC, Shanks RE. 1968. Summer climatic gradients and vegetation near Barrow, Alaska. Arctic 21: 161-171.

Congalton RG, Green K. 1999. Assessing the Accuracy of Remotely Sensed Data. CRC Press: Boca Raton.

Coppin P, Joncheere I, Muys B, Lampin E. 2002. Digital change detection methods in natural ecosystem monitoring: A review. In Analysis of Multitemporal Remote Sensing Images, Bruzzone L, Smits P (eds). World Science Publishing Co. Pte Ltd: Singapore; 3-26.

Environment Canada. 2004. Canadian Climate Normals or Averages 1971-2000. Environment Canada: Ottawa.

Fortier R, Aubé-Maurice B. 2008. Fast permafrost degradation near Umiujaq in Nunavik (Canada) since 1957 assessed from timelapse aerial and satellite photographs. In Proceedings of the Ninth International Conference on Permafrost, 29 June-July 2008. University of Fairbanks: Fairbanks, Alaska; 457-462.

Fortier R, LeBlanc AM, Wenbing Y. 2011. Impacts of permafrost degradation on a road embankment at Umiujaq in Nunavik (Québec), Canada. Canadian Geotechnical Journal 48: 720-740.

Fronzek S, Luoto M, Carter TR. 2006. Potential effect of climate change on the 
distribution of palsa mires in subarctic Fennoscandia. Climate Research 32: 1-12.

Gagnon RM, Ferland M. 1967. Climat du Québec septentrional. Québec, Service de la météorologie Ministère des richesses naturelles, 107pp.

GeoEye Elevating Insight. 2011. Imagery Sources. Editors: Digital Globe http:// www.geoeye.com/CorpSite/products-andservices/imagery-sources/ [5 May 2011].

Gomarasca MA. 2004. Bascis of Geomatics. Springer Verlag: Dordrecht, Heidelberg, London, New York.

Gopal S, Woodcock C. 1994. Theory and methods for accuracy assessment of thematic maps using fuzzy sets. Photogrammetric Engineering and Remote Sensing 60: 181-188.

Grey DR, Gessler PE, Hoppus M, Boudreau SL. 1998. Change Detection using NALC MSS Triplicates to Set Forest Planning Context. In Hansen M., Burk T. (eds). Integrated tools for natural resources inventories in the 21st century. Gen. Tech. Rep. NC-212. St. Paul, MN: U.S. Dept. of Agriculture, Forest Service, North Central Forest Experiment Station; 623-630.

Gurney SD. 2001. Aspects of the genesis, geomorphology and terminology of palsas: perennial cryogenic mounds. Progress in Physical Geography 29: 139-155.

Hachem S, Allard M, Duguay C. 2009. Using the MODIS land surface temperature product for mapping permafrost: an application to northern Québec and Labrador, Canada. Permafrost and Periglacial Processes 20(4): 407-416. DOI:10.1002/ ppp.672.

Hall FG, Botkin DB, Strebel DE, Woods KD, Goetz SJ. 1991. Large-scale Patterns of Forest Succession as Determined by Remote Sensing. Ecology 72: 628-640.

Hinkel KM, Jones BM, Eisner WR, Cuomo CJ, Beck RA, Frohn RC. 2007. Methods to assess natural and anthropogenic thaw lake drainage on the Western Arctic Coastal Plain of northern Alaska. Journal of Geophysical Research 112: F02S16.

Jia GJ, Epstein HE. 2004. Controls over intraseasonal dynamics of AVHRR NDVI for the Arctic tundra in northern Alaska. International Journal of Remote Sensing 25: 1547-1564.

Jolivel M. 2014. Érosion du pergélisol, transport fluvial et sédimentation marine, côte est de la baie d'hudson. Dissertation, Université Laval, Québec, Canada.

Jones BM, Grosse G, Hinkel KM, Arp CD, Walker S, Beck RA, Galloway JP. 2012. Assessment of pingo distribution and morphometry using an InSAR derived DSM, western Arctic Coastal Plain, northern Alaska. Geomorphology 138: 1-14.
Jorgenson MT, Racine CH, Walter JC, Osterkamp TE. 2001. Permafrost Degradation and Ecological Changes Associated with a Warming Climate in Central Alaska. Climate Change 48: 551-579. DOI: 10. 1023/A:1005667424292

Kauth RJ, Thomas GS. 1976. The Tasseled Cap-A graphic Description of the Spectral Development of Agriculture Crops as seen by Landsat. In In Proceedings of LARS 1976 Symposium on Machine Processing of Remotely Sensed Data, Purdue.

Kelley AM, Epstein H, Walker DA. 2004. Role of vegetation and climate in permafrost active layer depth in arctic tundra of Northern Alaska and Canada. Journal of Glaciology and Geocryology 26: 269-273.

Koeln G, Bissonnette J. 2000. Cross-correlation analysis: mapping landcover change with a historic landcover database and a recent, single-date multispectral image. In Proceedings 2000 ASPRS Annual Convention, Washingthon, DC.

Kranck EH. 1951. On the geology of the east coast of Hudson Bay and James Bay, observations during a research journay in summer 1947. Acta Geographica 11: 1-71.

Kravtsova VI, Bystrova AG. 2009. Changes in thermokarst lake sizes in different regions of Russia for the last 30yr, Kriosfera Zemli. Earth Cryosphere 13: 16-26.

Laberge MJ, Payette S. 1995. Long-Term Monitoring of Permafrost Changes in a Palsa Peatland in Northen Québec, Canada: 1983-1993. Arctic and Alpine Research 27: 167-171.

Lachenbruch AH, Marshall BV. 1986. Changing climate: geothermal evidence from permafrost in the Alaskan Arctic. Science 234: 689-696.

Langer M, Westermann S, Heikenfeld M, Dorn W, Boike J. 2013. Satellite-based modeling of permafrost temperatures in a tundra lowland landscape. Remote Sensing of Environment 135: 12-24. DOI:10.1016/ j.rse.2013.03.011.

Laprise D, Payette S. 1988. Evolution récente d'une tour-biere a palses (Québec subarctique): analyse cartographique et dendrochronologique. Canadian Journal of Botany 66: 2217-2227.

Lempke P, Ren J, Alley RB, Allison I, Carrasaco J, Flato G, Thomas Y, Zhang T. 2007. Observations: Changes in Snow, Ice and Frozen Ground. In Climate Change 2007: The Physical Science Basis. Contribution of Working Group I to the Fourth Assessment Report of the Intergovernmental Panel on Climate Change, Solomon SD, Qin D, Manning, Chen Z, Marquis M, Averyt KB, Tignor M, Miller H (eds). Cambridge University Press: Cambridge; 337-383.
Liu L, Schaefer K, Gusmeroli A, Grosse G, Jones BM, Zhang T, Parsekian AD, Zebker HA. 2014. Seasonal thaw settlement at drained thermokarst lake basins, Arctic Alaska. The Cryosphere 8: 815-826.

Luoto M, Heikinnen RK, Carter TR. 2004. Loss of palsa mires in Europe and biological consequences. Environmental Conservation 31: 1-8.

Lyons EA, Sheng Y, Smith LC, Junli L, Hinkel KM, Lenters JD, Wang J. 2013. Quanifying sources of errors in multitemporal mulitsensor lake mapping. International Journal of Remote Sensing 34: 7887-7905.

Mackay JR. 1974. Seismic shot holes and ground temperatures, Mackenzie Delta area, Northwest Territories. Geological Survey of Canada Paper, Part A 74: 389-390.

May I. 2011. Using in-field and remote sensing data to monitor permafrost dynamics in Northern Québec. Dissertation thesis, LMU, München: Fakultät für Geowissenschaften. http://edoc.ub.unimuenchen.de/13634/

Ménard E, Allard M, Michaud Y. 1998. Monitoring of ground surface temperatures in various biophysical micro-environments near Umiujaq, Eastern Hudson Bay, Canada. In Proceedings Permafrost - Seventh International Conference, Yellowknife (Canada). Collection Nordicana no. 55, 1998, 723-729.

Muster S, Heim B, Abnizova A, Boike J. 2013. Water Body Distributions Across Scales: A Remote Sensing Based Comparison of Three Arctic Tundra Wetlands. Remote Sensing 5(4): 1498-1523. DOI:10. 3390/rs5041498.

NASA. 2000. Measuring Vegetation (NDVI \& EVI). http://earthobservatory.nasa.gov/Features/MeasuringVegetation/

measuring_vegetation_3.php [16 November 2014].

Nelson FE, Shiklomanov NI, Mueller GR, Hinkel KM, Walker DA, Bockheim JG. 1997. Estimating active-layer thickness over a large region: Kuparik River basin, Alaska, USA. Arctic and Alpine Research 29: $367-378$.

Nelson FE, Brigham L, Hinkel KM, Romanovsky VE, Smith O, Tucker W, Vinson T. 2003. Climate Change, Permafrost and Impacts on Civil Infrastructure. Special Report 01-03, Permafrost Task Force, US Arctic Research Commission, Arlington, VA, 72pp.

Osterkamp TE, Romanovsky VE. 1999. Evidence for warming and thawing of discontinuous permafrost in Alasaka. Permafrost and Periglacial Processes 10: 17-37. DOI: $\quad 10.1002 /(\mathrm{SICI}) 1099-1530(199901 /$ 03) $10: 1<17::$ AID-PPP303 > 3.0.CO;2-4 
Panda SK, Prakash A, Solie DN, Romanovsky VE, Jorgenson MT. 2010. Remote sensing and field-based mapping of permafrost distribution along the Alaska Highway corridor, Interior Alaska. Permafrost and Periglacial Processes 21: 271-281. DOI: 10.1002/ppp.686

Pettorelli N, Vik JO, Mysterud A, Gaillard JM, Tucker CJ, Stenseth NC. 2005. Using the satellite-derived NDVI to assess ecological responses to environmental change. Trends in Ecology and Evolution 20: 503-510.

Pissart A. 2002. Palsas, lithalsas and remnants of these periglacial mound. A progress report. Progress in Physical Geography 26: 605-621.

Raynolds MK, Walker DA. 2008. Relationship of permafrost characteristics, NDVI, and arctic vegetation types. In Ninth International Conference on Permafrost Proceedings, Institute of Northern Engineering: University of Alaska Fairbanks, USA. 1, 1469-1474.

Romanovsky VE, Osterkamp TE. 1995. Interannual variations of thermal regime of active layer and near-surface permafrost in northern Alaska. Permafrost and Periglacial Processes 6: 313-335. DOI: 10.1002/ppp.3430060404

Schowengerdt RA. 1997. Remote Sensing. Models and Methods for Image Processing. Elsevier Academic Press: San Diego.

Seppälä M. 1988. Palsas and related forms. In Advances in periglacial geomorphology,
Clark MJ (ed). John Wiley \& Sons, Inc.: Chichester; 247-278.

Smith SL, Sheng Y, MacDonald GM, Hinzman LD. 2005. Disappearing Arctic lakes. Science 308: 1429.

Smith SL, Romanovsky VE, Lewkowicz AG, Burn CR, Allard M, Clow GD, Yoshikawa K, Throop J. 2010. Thermal State of Permafrost in North America: A Contribution to the International Polar Year. Permafrost and Periglacial Processes 21: 117-135. DOI: 10.1191/0309133302pp354ra

Stein A, van der Meer F, Gorte B. 1999. Spatial Statistics for Remote Sensing. Kluwer Academic Publishers: Dordrecht.

Stow DA, Hope A, Mcguire D, Verbyla D, Gamona J, Huemmrich F, Houston S, Racine C, Sturm M, Tape K, Hinzman L, Yoshikawa K, Tweedie C, Noyle B, Silapaswan C, Douglas D, Griffith B, Jia G, Epstein H, Walker D, Deaschiner S, Peterson A, Zhou L, Myneni R. 2004. Remote sensing of vegetation and landcover change in Arctic Tundra Ecosystems. Remote Sensing of Environment 89: 281-308.

Sushama L, Laprise R, Allard M. 2006. Modeled current and future soil thermal regime for northeast Canada. Journal of Geophyical Research 111: D18111. DOI: 10.1029/2005JD007027

Tansey KJ. 2006. Normalized Difference Vegetation Index. In Our Earth Changing
Land. Geist H (ed). Greenwood Press: Westport; 446.

Westermann S, Langer M, Boike J. 2011. Spatial and temporal variations of summer surface temperatures of high-arctic tundra on Svalbard - implications for MODIS LST based permafrost monitoring. Remote Sensing of Environment 115(3): $908-922 . \quad$ DOI: $10.1016 /$ j.rse. 2010.11.018.

Williams PJ, Smith MW. 1989. The Frozen Earth. Fundamentals of Geocryology. Cambridge University Press: New York.

Wilson SD, Nilsson C. 2009. Arctic alpine vegetation change over 20 years. Global Change Biology 15: 1676-1684. DOI:10. 1111/j.1365-2486.2009.01896.x.

Xu H, Young JA. 1990. Monitoring changes in land use through integration of remote sensing and GIS. In Proceedings of IGARSS '90 Symposium, Maryland; College Park, MD: University of Maryland; 957-960.

Zhao L, Ping C-L, Yang D, Cheng G, Ding Y, Liu S. 2004. Changes of climate and seasonally frozen ground over the past 30 years in Qinghai-Xizang (Tibetan) Plateau, China. Global and Planetary Change 43: 19-31.

Zoltai SC, Tarnocai C. 1971. Properties of a wooded palsa in northern Manitoba. Arctic and Antarctic Research 8 115-129. 